\title{
Measuring Business Cycles: A Review
}

\author{
Marinko Škare', Saša Stjepanović ${ }^{1}$
}

\begin{abstract}
This article summarizes the main findings on problems related to the measurement and identification of business cycles. The aim of this study is to define and identify the determinants of business cycles. This paper provides an overview of the methodology and its future course. Our investigation suggests that some methodological frameworks are available in the literature, but none is perfect. A new development in the field lies in spectral analysis methods for measuring business cycles, which may have advantages over existing methodologies (nonlinearity, stationarity issues). We feel that fractional integration is important in the proper monitoring and explanation of business cycles. Spectral analysis techniques have also proved to be useful for addressing the problems of stationarity and structural breaks in time series when analyzing business cycles. Another important issue that is excluded when studying business cycles is that the link between cycles and economic growth is presumed to be non-existent, implying money neutrality.
\end{abstract}

KEY WORDS: $\quad$ economic growth, cycles, contraction, recession, total factor productivity

JEL Classification: E30, E32, F44

'Juraj Dobrila University of Pula - Faculty of economics and Tourism "Dr. Mijo Mirkovic", Croatia

\section{Introduction}

Economic expansions and slowdowns are inherent in economic systems. Finding mechanisms through which to prolong expansions and limit, or at least alleviate, recessions is in the focus of macroeconomic theory and policy. That the recent financial crisis came as a surprise to a majority of economic experts reemphasizes to those in the economic discipline the necessity of identifying turning points in the economy.

The process of measuring business cycle requires defining the cycle, defining criteria for distinguishing between business cycles and other similar fluctuations, defining procedures for the detection of business

Correspondence concerning this article should be addressed to: Marinko Škare, Juraj Dobrila University of Pula - Faculty of economics and Tourism "Dr. Mijo Mirkovic", Preradoviceva 1/1 Pula Istarska zupanija 52100,Croatia, E-mail: mskare@unipu.hr cycles and defining methods for measuring business cycles. The main aim of today's macroeconomic policy is to understand the functioning of the business cycle.

The terms business cycle or economic cycle refer to a change in the economic activity of a country during a particular period. Changes in economic activity can occur in two directions: a period of relatively rapid economic growth and expansion or a period of decline and contraction. The real gross domestic product (GDP) is a common way of measuring and determining the strength of a business cycle.

In 1819 , the dominant theory was the theory of general equilibrium. That year, a paper entitled Nouveaux principes déconomie politique by Jean Charles Léonard de Sismondi was published, which studied the existence of periodic economic crises that form business cycles. Before this work, classical economists had denied the existence of business cycles. Classical 
economists blamed war as a leading cause of business cycles in the economy. However, Sismondi was the first to discover the existence of cycles by examining an economic crises that occurred during peacetime.

In recent years, economic theory has addressed monitoring and measuring economic fluctuations rather than measuring business cycles. Recent studies that used spectral analysis methods have proved the existence of business cycles in world GDP.

In this paper, we show how the theory and measurement of business cycles were developed over the years, we will define business cycles, we will show what causes business cycles, and we will assess the future of business cycle measurement.

In section 2, definitions of the business cycle are reviewed based on various theoretical and empirical explanations. Section 3 investigates the primary sources of business cycles, while section 4 present different methods for measuring cycles. Section 5 provide concluding remarks on open questions in measuring business cycles, providing new insights into how these issues can be addressed to expand knowledge in the business cycles literature.

\section{Defining the Business Cycle}

The idea that the market economy functions under recurring fluctuations depending on a number of variables was formalized by Mitchell (1927), Burns and Mitchell (1946) as follows:

"Business cycles are a type of fluctuation found in the aggregate economic activity of nations that organize their work mainly in business enterprises: a cycle consists of expansions occurring at about the same time in many economic activities, followed by similarly general recessions, contractions and revivals which merge into the expansion phase of the next cycle; this sequence of changes is recurrent but not periodic; in $d u$ ration business cycles vary from more than one year to ten or twelve years; they are not divisible into shorter cycles of similar character with amplitudes approximating their own.".

Today, this definition serves as the foundation of modern thinking about business cycles, in so far as it concerns the measurement of business cycles or the construction of cyclical fluctuation models. Burns and Mitchell have noted that this definition creates many new issues. For example, if we look at the fluctuations in the overall economic activity of a nation, then we should take into account the differences between business cycles in different regions. Further, questions arise as to whether business cycles should be studied in an international or national context, whether there is a historical nature of business cycles, and whether business cycles change over time. Likewise, if we take into account Burns and Mitchell's remark that "expansion that occurs in many economic activities", we need to define and aggregate the activities. The fact that economic activities occur at around the same time suggests the possibility that some macroeconomic variables are formed before (leading) and after some cycles (lagging). Looking at these "recurring changes", we need to determine how we should address seasonal changes, random fluctuations and secular trends. Furthermore, the comments relating to the duration and amplitude of business cycles are based on actual observations of cyclical phenomena and the rules for excluding irregular movement and other similar changes.

The National Bureau of Economic Research has access to data that allow the identification of the business cycle, which occurs in two steps: first, find the cyclical peaks and troughs in the observed economic variables and, second, determine whether these changes are common enough through all the observed series. If the answer to the second question is affirmative, then the aggregate business cycle or reference cycle is identified. Once the reference dates are found, the cyclical behavior of each series is discussed as the reference cycle. As a part of this analysis, the duration, time and amplitude of each cycle are compared to those of the reference period. In its method of studying business cycles, the NBER identifies business cycles based on (absolute) declines or changes in the general level of production. Such an approach is known as a classic example of the business cycle. There are alternative approaches that consider whether the fall in the series originated as a deviation from its long-term trend, which in Zarnowitz's terminology (1992), are known as growth cycles. Note that one advantage of using the growth cycle is that expansion and contraction of the business cycle are of approximately the same duration. 
In classic cycles, the recession is usually shorter than the expansion due to growth effects.

If we decide to use growth cycles, the question arises as how to identify the cyclical component of a particular series. According to King et al. (1991), models of the real business cycle (RBC), which enable a trend in technological shocks, imply that growth and business cycles are mutually determined. The practice of separating the trend and cyclical components using linear time series methods are well established. There are several approaches to de-trending economic time series. One approach is to use linear de-trending procedures that assume that the observed series has a deterministic time trend. An alternative approach is to assume that the stochastic trend is modeled with a unit root in the time series. The major contribution of Nelson and Plosser (1982) to this analysis is, in fact, that they have proved that economic time series, such as those of real GDP, usually have a unit root. However, Stock and Watson (1998) argue that linear time trends or first differentiation to eliminate the unit root do not provide satisfactory results for identifying the cyclical component series of the observed data. Note that while the first approach to linear time trends leads to the generation of false effects of business cycles in de-trending series, in the second, first differentiation exacerbates the role of short-term noise.

Several alternative approaches have been recently proposed in the business cycles literature to address the separation of the trend from the cyclical components of the time series. One of these approaches is the so-called Hodrick-Prescott (HP) filter, which minimizes the quadratic form to determine the trend component in a given series:

$y_{t}=\tau_{t}+c_{t}$,

where $\tau_{t}$ represents the trend component, and $c_{t}$ represents the cyclical component. $\tau_{t}$ may be nonstationary and may contain a deterministic and stochastic trend. The primary objective was to assess $c_{t}$, a stationary cyclical component that is derived from stochastic cycles of different periods of time. The trend component is calculated as $\tau_{t}=y_{t}-c_{t}$.

The properties of the HP filter are studied by many authors, including Singleton (1988), King and Rebelo (2000), and Cogley and Nason (1995). Cogley and Nason claim, in particular, that dynamic business cycles obtained using HP de-trending methods depend on the characteristics of the studied data. If they are stationary, then the de-trending procedure has favorable characteristics. If the observed data are non-stationary, the HP filter produces spurious business cycle fluctuations.

The second approach is based on the spectral analysis of economic time series. The band-pass filter, which filters and traces the long-term trend of the high-frequency changes in a observed time series, was developed by Baxter and King (1999). The approach maintains the components that are associated with the periodicity of a typical business cycle. Usually, this periodicity is between six quarter and eight years. The band-pass filter of Baxter and King (1999) is obtained by applying the Kth order moving average of a given time series:

$y_{t}^{*}=\sum_{k=K}^{K} \alpha_{k} y_{t-k}$

where the ratio of the moving average is selected to be symmetrical, $a_{k}=a_{-k}$ for $k=1, \ldots \ldots, K$, showing that if the sum of the coefficients of the moving average is zero, $\sum_{k=K}^{K} \alpha_{k}=0$, then there is a characteristic of trend elimination.

The Baxter-King filter will eliminate deterministic quadratic trends, or it will produce a stationary series that is integrated of order two or less. This filter is designed to have a range of other features, including that the results should not depend on the sample size and not change the relationship between time series at any frequency. Baxter and King created a band-pass filter, taking into account low-pass and high-pass filters with the required properties.

The various methodologies used by scholars in defining business cycles are evident from Table 1.

\section{The Origins of Cycles}

One of the most common and challenging questions in macroeconomics is related to the business cycle: Which shocks cause business fluctuations? In economic theory, most responses to this question implicate monetary and fiscal policies or oil shocks. To that list, Prescott (1986) adds the impact of technological shocks and argues that technological shocks in the post-war period were, in more than $75 \%$ of 
Table 1. Methods for Identifying Business Cycles

\begin{tabular}{|c|c|}
\hline Authors & Methods for defining business cycles \\
\hline Burns and Wesley (1946) & Business cycles are a type of fluctuation in aggregate economic activity \\
\hline $\operatorname{NBER}(2010)$ & Business cycles are based on two parts: cyclical peaks and bottoms \\
\hline Zarnowitz (1992) & $\begin{array}{l}\text { Considers growth cycles where the fall in the series is determined by the } \\
\text { deviation from the long-term trend. }\end{array}$ \\
\hline King, Plosser and Stock (1991) & $\begin{array}{l}\text { Using a model of real business cycle, they implied that growth and business } \\
\text { cycles are mutually determined }\end{array}$ \\
\hline $\begin{array}{l}\text { Singleton (1988), King and Rebelo (1998), } \\
\text { Cogley and Nason (1995) }\end{array}$ & $\begin{array}{l}\text { An alternative approach for defining business cycles using the Hodrick- } \\
\text { Prescott filter }\end{array}$ \\
\hline Baxter and King (1999) & $\begin{array}{l}\text { Another alternative approach for defining business cycles using spectral } \\
\text { analysis of time series }\end{array}$ \\
\hline
\end{tabular}

Table 2. Key Determinants of Business Cycles

\begin{tabular}{|c|c|}
\hline Authors & What causes business cycles? \\
\hline Prescott (1986) & $\begin{array}{l}\text { Considers the impact uncertainty of technological shocks in the post -war } \\
\text { period }\end{array}$ \\
\hline Norrbin (1988) & Measures TFP (total factor productivity) using military spending \\
\hline Evans (1992) & Measures TFP using indicators of monetary policy \\
\hline $\begin{array}{l}\text { Gali (1999), King et al. (1991), Nelson and } \\
\text { Plosser (1982), King and Rebelo (1999) }\end{array}$ & Discuss the importance of technology shocks as pulses in business cycles \\
\hline $\begin{array}{l}\text { Kim and Lougani (1992), Rotemberg and } \\
\text { Woodford (1996), Finn (2000) }\end{array}$ & $\begin{array}{l}\text { Consider shocks in the oil industry instead of technological progress as the } \\
\text { main variable that causes business cycles }\end{array}$ \\
\hline $\begin{array}{l}\text { Christiano and Eichenbaum (1992), Baxter and } \\
\text { King (1999), Braun (1994) and McGrattan (1994) }\end{array}$ & $\begin{array}{l}\text { Consider fiscal shocks instead of technological progress as the main variable } \\
\text { that causes business cycles }\end{array}$ \\
\hline $\begin{array}{l}\text { Ramey and Shapiro (1998), Burnside et al. } \\
\text { (1996) and Fisher (2003) }\end{array}$ & $\begin{array}{l}\text { Take into account the effects of changes in government spending on } \\
\text { business cycles }\end{array}$ \\
\hline $\begin{array}{l}\text { Bernanke, Gertler and Gilchrist (1996), Dixit } \\
\text { and Stiglitz (1977) }\end{array}$ & $\begin{array}{l}\text { Consider monetary shocks instead of technological progress as the main } \\
\text { variable that causes business cycles }\end{array}$ \\
\hline Farmer (1999) & $\begin{array}{l}\text { Takes the basic RBC model as starting point to model multiple equilibria for } \\
\text { determining causes of business cycles }\end{array}$ \\
\hline
\end{tabular}

cases, the causes of business fluctuations. The idea of technology shocks as a main driver of business cycles is among the more controversial ideas. Prescott calculates total factor productivity (TFP) and treats this as a measure of exogenous technology shocks. However, there are reasons to distrust that TFP measures real shocks in technology. TFP can be forecast using military spending, as conducted by Norrbin (1988), or using indicators of monetary policy, as conducted by Evans (1992). In both modes, observed variables are unlikely to have an impact on the rate of technical progress. This evidence suggests that TFP, which Prescott calculates, is not the pure exogenous shock he observes. Instead, they already include endogenous components. The utilization of capital variable observed by Basu (1996), and Burnside, Eichenbaum 

relation between hours worked and average labor productivity. Fiscal shocks also have increased volatility in output that is generated in real business cycle models. The effects of financial contagion and economic crisis on major financial markets are discussed in Dajčman (2014), showing that contagion is not strongly connected to the crisis. Fiscal stimulus can speed up economic recovery by attracting foreign direct investments, but it is supported by other non-fiscal factors, mainly infrastructure and political stability (Rădulescu and Druica, 2014).

However, there is a lack of cyclical variation in taxes and government spending for fiscal shocks to be the primary cause of business fluctuations. Cyclical movements in public expenditures are relatively small; during periods of war there is usually a temporary increase in government spending. Ohanian (1997) shows that models of real business cycles can explain the main macroeconomic elements of war episodes: a moderate decrease in consumption, a substantial decline in investment, and a significant increase in working hours. These features occur naturally in real business cycle models in which government spending is financed by lump-sum taxes. Additional government spending must eventually be funded from taxes. The wealth of households declines as the corporate taxes grows. In response to this reduction, households reduce their consumption and increase their number of working hours, reducing the number of hours used for leisure. This increase in working hours creates a moderate increase in production. Because the current marginal propensity to consume is reduced, households prefer to pay taxes related to war, so as to reduce consumption today and in the future. Because such spending cuts today occur with an increase in output, which is smaller than the increased government spending, there is a reduction in investment. Cooley and Ohanian (1997) use a model of the real business cycle to compare the social implications of different strategies of war financing. Ramey and Shapiro (1998) take into account the effects of changes in government spending. Burnside, Eichenbaum and Fisher (2004) study the impact of a large current increase in government expenditures in the presence of a taxation distortion. A possible link between labor markets and business cycles is explored in Tomić (2014).

The following observed effect is the impact of specific investments in technological change. One of the natural alternatives to technological shocks is an investment, in particular, in technological change. In the standard model of the real business cycle, positive technology shocks make both work and existing capital more productive. In contrast, specific investments in technological advances do not affect the productivity of old capital goods. Instead, new capital allows greater productivity and lower costs, resulting in an increase in the real rate of return on investment. We can measure the pace of specific investments in technological change by the relative price of investment goods in terms of consumption goods. According to the data constructed by Gordon (1990), relative prices have dramatically declined over the past forty years. Based on these observations, Greenwood, Hercowitz and Krusell (2000) use growth accounting methods to claim that 60 percent of post-war growth in the output per worker-hour ratio is derived from investments in particular technological changes. Using VAR, which is identified with long-term restrictions, Fisher (2003) believes that investing in particular technological changes affects 50 percent of the variation in hours worked and 40 percent of the variation in the quantity of output. On the contrary, he believes that technological shocks affect less than 10 percent of the variation in output and hours worked. Because of Greenwood, Hercowitz and Krusell (1997), investments in technological change, in particular, have become one of the standard shocks included in real business cycle models.

The following observed effect is the impact of monetary shocks. There are some studies on the impact of monetary shocks on real business cycle models that are extended to contain additional elements of real and nominal friction. Researchers such as Bernanke, Gertler, and Gilchrist (1996) emphasize the role of credit friction in response to the technological economy and monetary shocks. Another important element is monopolistic competition, modeled according to Dixit and Stiglitz (1977). In basic models of the real business cycle, companies and employees have acquired prices from perfectly competitive markets. Such an environment is less meaningful to observe the enterprise than are those in which they choose their prices or employees as those who want the reward (performance-based pay). Introducing monopolistic competition to the production and la- 

that the logarithm economic activities at the turning point of cycles equal the logarithm of overall economic activity. Some, e.g., the Institute for Economic Business Cycles, have studied tilting point in cycles as opposed to $\Delta y_{t}$ data. At the time when Mitchell began his work on alternative views of $y_{t}$, which is seen as a periodic component, the sine and cosine represent waves:

$y_{t}=\sum_{j=1}^{m} \alpha_{j} \cos \lambda_{j} t+\beta_{j} \sin \lambda_{j} t$

where $\lambda_{j}$ is the frequency rate, and $j$ represents the oscillation. If $m=1$, then there is only one periodic cycle. The problem of this representation is that it has small economic time series that shows evidence of periodicity.

As mentioned above, the next step in measuring business cycles is to locate the turning point. To be able to locate the turning points in a particular series, some way to identify them in a time series should be defined and created. One of the most practical solutions is that the peaks are local maxima in the time series $y_{t}$. In this case, if the carets $\vee_{t}\left(\wedge_{t}\right)$ are binary variables, having value 1 as local extrema and zero otherwise. Formally, we obtain the following (Harding and Pagan, 2004):

$\vee_{t}=1\left(y_{t}<y_{t \pm j}, 1 \leq j \leq k\right)$

$\wedge_{t}=1\left(y_{t}>y_{t j \pm}, 1 \leq j \leq k\right)$

Turning points can also be located through alternative methods. An alternative approach for locating the turning points is based on the fundamental processes in the model. The above procedure does not require any knowledge of the process generating the $y_{t}$ data. An alternative approach is to apply the model using $\Delta y_{t}$, which is then used for the location of tipping point. Today, such models are parametric and feature two modes. One of the most popular parametric models is that of Hamilton (1989), where the growth rate is treated with a Markov switching process of the form:

$\Delta y_{t}=\mu_{0}\left(1-\xi_{t}\right)+\mu_{1} \xi+e_{t}$,

where $\mu_{j}$ represents the growth rates in the regimes, and they are indexed by latent binary state $\xi_{t}$, with $e_{t}$ as a normally distributed, zero mean error term $\mu 0$. This model represents a state of low growth rates, and $\mu_{1}$ represents a state of high growth rates. The model is completed in a manner that specifies the probability of transition from a state $\xi_{t-1}=0$ or 1 to a state $\xi_{t}=1$ or 0 . The model may be more complex, and the extra dynamics and different variances of each of the arrangement thus enable the probability of transition to depend on the observed data.

Measuring cycle features is the next step in the procedure. The process of locating the turning point separates the time series into stages. The expansion phase starts from the next peak; the contraction phase extends from the peak to the next base. What follows in the model is most easily described as a derivation of the information in the extension.

Two fundamental pieces of data are required in the growth stages: duration and amplitude. The length of the expansion stage represents the number of periods between the bottom and top, whereas the amplitude is a measure that shows changes in $y_{t}$ from bottom to top. In many cases, the $y_{t}$ logarithm of some variable, such as GDP or industrial production, is used, and in such cases, the amplitude is explained as the percentage change in $y_{t}$ between the bottom and top. Connecting the bottom and the top yields the hypotenuse. If $y_{t}=\ln Y_{t}$, then the hypotenuse represents the path followed by the variable that shows steady growth during the expansion. If this is taken into consideration, then it is instructive to study the movement of the actual data on the path of constant growth that is represented by the hypotenuse.

Burns and Mitchell's famous definition of the business cycle includes two aspects. First, we need to identify the aggregate economic activity, and the second requirement is the existence of synchronization among different variables during certain phases of the business cycle. The authors consider that GDP is a good measure of economic activity, although others, such as Moore and Zarnowitz (1986), prefer to have a weighted average of several series and not just one series. Given that GDP as a measure was not available to Burns and Mitchell, there were no data for the period that they needed, so it is natural that they have given emphasis to the second component of their definition of business cycles, i.e., the synchronization of cyclespecific series representing economic activity. Burns and Mitchell determined the turning points in number of series and then determined the reference cycle in a way that sets the dates around which peaks and troughs of business cycles revolve. Moreover, at the 
end of the process, it is necessary to know the extent to which each particular cycle is synchronized with aggregate cycles.

\section{Conclusion}

In this paper, we presented a history of business cycles measurement and the problems associated with that process. In the first part, we have explained the concept and definition of the business cycle. Through the definition of the business cycle, we reached some new and unresolved issues that have emerged out of the definition. In the second part, we have addressed causes such as exogenous effects of technology shocks on business cycles. We have also considered the ratio of total factor productivity and technology shocks and emphasized the exogenous and endogenous effect of technology shocks. We have subsequently presented some other shocks (the influence of oil shocks, monetary shocks, and fiscal shocks) that can replace technological shocks in measuring business cycles. The paper also presents an overview of new models of business cycles showing differences in steps; determining the turning points, peaks and troughs of business cycles; developing the hypotenuse and automatic connection between trough and peak; and decomposing the business cycle curve.

Although Burns and Mitchell represented a relatively significant discovery in the measurement of business cycles, their findings were not initially accepted in academic circles. Today, this has changed an increasing number of people and scholars accept their method for several reasons, the most important being that today it is much easier to estimate turning points in the business cycle with individual models an important step in their analysis. Further, it should be noted that today there enough emerging research facilitating advances through tools that simulate data much more accurately than previously possible. From our study, we can conclude that there is no one solution for measuring business cycles that would be accepted by the profession. All of the above solutions have their shortcomings, which are objectively presented in this paper.

As for the future, there are many areas that are being investigated and solutions that are being looked into. We have attempted a new approach to measuring business cycles that tries to address these short- comings. We introduce multi-regime Markov switching VAR, HP (Hedrick Prescott) filters and spectral analysis as the latest developments in the study of business cycle movements. We are of the opinion that fractional integration is also important for proper business cycles monitoring and explanation (Škare \& Stjepanovic, 2013) and that the impact of information and prices from the firm perspective also plays a role in business cycle dynamics (Mäkinen \& Ohl, 2015).

\section{References}

Altig, D., Christiano, L. J., Eichenbaum, M., \& Linde, J. (2011). Firm-Specific Capital, Nominal Rigidities and the Business Cycle. Review of Economic Dynamics, 14 (2), 225-247.

Araújo, E. (2015). Monetary policy objectives and Money's role in U.S. business cycles. Journal of Macroeconomics, 45, 85-107.

Basu, S. (1996). Procyclical Productivity, Increasing Returns of Cyclical Utilization? Quarterly Journal of Economics, 111 (3), 719-751.

Baxter, M., King, R. (1999). Fiscal Policy in General Equilibrium. American Economic Review, 83 (3), 315-334.

Bernanke, B., Gertler, M., Gilchrist, S. (1996). The Financial Accelerator in a Quantitative Business Cycle Framework. Review of Economics and Statistics, 78 (1), 1-15.

Braun, R. A. (1994). Tax Disturbances and Real Economic Activity in the Postwar United States. Journal of Monetary Economics, 33 (3), 441-462.

Burns, A., Mitchell, W. C. (1946). Measuring Business Cycles (Vol. 2). New York, NY: National Bureau of Economic Research.

Burnside, C., Eichenbaum, M., \& Rebelo, S. (1993). Labour Hoarding and the Business Cycle. Journal of Political Economy, 101 (2), 245-273.

Burnside, C., Eichenbaum, M., \& Rebelo, S. (1996). Sectoral Solow Residuals. European Economic Review, 40 (3-5), 861-869.

Burnside, C., Eichenbaum, M., \& Fisher, J. (2004). Fiscal shocks and their consequences. Journal of Economic Theory, 115 (1), 89-117.

Cavallo, A., Ribba, A. (2015). Common macroeconomic shocks and business cycle fluctuations in Euro area countries. International Review of Economics \& Finance, 38, 377-392. 
Chari, V., Kehoe, P., McGrattan, E. (2004). Are structural VARs with long-run restrictions useful in developing business cycle theory? (Staff Report No. 364). Federal Reserve Bank of Minneapolis.

Christiano, L. J., Eichenbaum, M. (1992). Current realbusiness-cycle theories and aggregate labor-market fluctuations. The American Economic Review, 82 (3), 430-450.

Christiano, L. J., Eichenbaum, M., \& Vigfusson, R. (2003). What happens after a technology shock? (Working Paper No. 9819). National Bureau of Economic Research.

Cogley, T., Nason, J. (1995). Output Dynamics in Real Business Cycle Models. American Economic Review, 85 (3), 492-511.

Cooley, T. F., Ohanian, L. E. (1997). Postwar British economic growth and the legacy of Keynes. Journal of Political Economy, 105 (3), 439-472.

Dajčman, S. (2014). Was there a contagion between major European and Croatian stock markets? An analysis of co-exceedances. Economic ResearchEkonomska Istraživanja, 27 (1), 155-168.

Dixit, A., Stiglitz, J. (1977). Monopolistic Competition and Optimum Product Diversity. American Economic Review, 67 (3), 298-308.

Evans, L. (1992). Productivity Shocks and Real Business Cycles. Journal of Monetary Economics, 29 (2), 191-208.

Farmer, R. (1999). Macroeconomics of Self-fulfilling Prophecies (2nd ed.). Cambridge, MA: MIT Press.

Finn, M. (2000). Perfect Competition and the Effects of Energy Price Increases on Economic Activity, Journal of Money, Credit and Banking, 32 (3), 400-416.

Fisher, J. (2003). Technology Shocks Matter (Working Paper No. 02-14). Federal Reserve Bank of Chicago.

Gali, J. (1999). Technology, Employment and the Business Cycle: Do Technology Shocks Explain Aggregate Fluctuations? American Economic Review, 89 (1), 249-271.

Gali, J., Lopez-Salido, J. D., Valles, J. (2003). Technology Shocks and Monetary Policy: Assessing the Feds Performance. Journal of Monetary Economics, 50 (4), 723-743.

Gordon, R. (1990). The Measurement of Durable Goods Prices. Chicago, IL: University of Chicago Press.

Greenwood, J., Hercowitz, Z., \& Krusell, P. (2000). The Role of Investment-Specific Technological
Change in the Business Cycle. European Economic Review, 44 (1), 91-115.

Greenwood, J., Hercowitz, Z., \& Krusell, P. (1997). Long-Run Implications of Investment-Specific Technological Change. American Economic Review, 87 (3), 342-362.

Guo, J. T., Sirbu, A. I., Weder, M. (2015). News About Aggregate Demand and the Business Cycle. Journal of Monetary Economics, 72, 83-96.

Hamilton, J. D. (1989). A new approach to the economic analysis of nonstationary time series and the business cycle. Econometrica, 57 (2), 357-384.

Harding, D., Pagan, A. (2006). Measurement of Business Cycles. University of Melbourne, Department of Economics Research Paper 966

Jaimovich, N., Floetotto, M. (2008). Firm Dynamics, Markup Variations, and the Business Cycle. Journal of Monetary Economics, 55 (7), 1238-1252.

Khorunzhina, N. (2015). Real Business-Cycle Model with Habits: Empirical Investigation. Economic Modelling, 46, 61-69.

Kim, I. M., Loungani, P. (1992). The Role of Energy in Real Business Cycle Models. Journal of Monetary Economics, 29 (2), 173-189.

King, R. G., Plosser, C. I., Rebelo, S. T. (1988). Production, growth, and business cycles I: The basic neoclassical model. Journal of Monetary Economics, 21 (2-3), 195-232.

King, R., Plosser, C., Stock, J., Watson, M. (1991). Stochastic Trends and Economic Fluctuations. The American Economic Review, 81 (4), 819-840.

King, R. G., Rebelo, S. T. (1999). Resuscitating real business cycles in Handbook of macroeconomics. In J. B. Taylor \& M. Woodford (Eds.), Handbook of Macroeconomics (Vol. 1, pp. 927-1007). Amsterdam: Elsevier.

King, R., Rebelo, S. (2000). Resuscitating Real Business Cycles (Working Paper No. 7534). National Bureau of Economic Research.

Lee, Y., Mukoyama, T. (2015). Entry and Exit of Manufacturing Plants Over the Business Cycle, European Economic Review, 77, 20-27.

Mäkinen, T., Ohl, B. (2015). Information Acquisition and Learning from Prices Over the Business Cycle. Journal of Economic Theory, 158, 585-633.

McGrattan, E. R. (1994). The Macroeconomic Effects of Distortionary Taxation. Journal of Monetary Economics, 33 (3), 573-601. 
Mitchell, W. C. (1927). Business Cycles: The Problem and Its Setting. New York, NY: National Bureau of Economic Research.

Moore, G. H., Zarnowitz, V. (1986). Major Changes in Cyclical Behavior. In R. J. Gordon (Ed.), The American Business Cycle: Continuity and Change (pp. 519-582). Chicago, IL: University of Chicago Press.

National Bureau of Economic Research, Business Cycle Dating Commitee (2010). Available at http://www. nber.org/cycles/sept2010.html

Nelson, C., Plosser, C. (1982). Trends and Random Walks in Macroeconomic Time Series: Some Evidence and Implications. Journal of Monetary Economics, 10 (2), 139-162.

Norrbin, S. C. (1988). The Relation Between Price and Marginal Cost in U.S. Industry. A Contradiction. Journal of Political Economy, 101 (6), 1149-1164.

Ohanian, L. (1997). The Macroeconomic Effects of War Finance in the United States: World War II and the Korean War. American Economic Review, 87 (1), 23-40.

Prescott, E. (1986). Theory Ahead of Business-Cycle Measurement (Staff Report No. 102). Federal Reserve Bank of Minneapolis.

Rădulescu, M., Druica, E. (2014). The Impact of Fiscal Policy on Foreign Direct Investments. Empiric Evidence from Romania. Economic Research-Ekonomska Istraživanja, 27 (1), 86-106.

Ramey, V., Shapiro, M. (1998). Costly Capital Reallocation and the Effects of Government Spending. Carnegie-Rochester Conference Series on Public Policy, 48 (1), 145-194.

Rotemberg, J. J., Woodford, M. (1996). Real-businesscycle models and the forecastable movements in output, hours, and consumption. The American Economic Review, 86 (1), 71-89.

Shakina, E., Barajas, A. (2014). The Dynamics of Intellectual Resources During the Economic Crisis. Economic Research-Ekonomska Istraživanja, 27 (1), 861-881.

Singleton, K. (1988). Econometric issues in the analysis of equilibrium business cycle models. Journal of Monetary Economics, 21 (2-3), 361-386.

Škare, M., Stjepanović, S. (2013). A Fractionally Integrated Model for the Croatian Aggregate Output (GDP) Series. Ekonomska istraživanja - Economic Research, 26 (2), 289-330.
Stock, J., Watson, M. (1999). Business Cycle Fluctuations in U.S.Macroeconomic Time Series. In J. B. Taylor, \& M. Woodford (Eds.), Handbook of Macroeconomics (Vol. 1, pp. 3-65). Amsterdam: Elsevier.

Tomić, I. (2014). Structural Unemployment in Croatia - How Important Is the Occupational Mismatch? Economic Research-Ekonomska Istraživanja, 27 (1), 346-365.

Zarnowitz, V. (1992). Business Cycles Theory, History, Indicators and Forecasting. Chicago, IL: The University of Chicago Press.

\section{Acknowledgments}

This work has been fully supported by the Croatian Science Foundation as project no. 9481, "Modeling Economic Growth - Advanced Sequencing and Forecasting Algorithm." Note: Any opinions, findings and conclusions or recommendations expressed in this material are those of the author(s) and do not necessarily reflect the views of the Croatian Science Foundation. 
